\title{
Interactive comment on "Modeling the smoky troposphere of the southeast Atlantic: a comparison to ORACLES airborne observations from September of 2016" by Yohei Shinozuka et al.
}

Yohei Shinozuka et al.

yohei.shinozuka@nasa.gov

Received and published: 15 June 2020

The comment was uploaded in the form of a supplement: https://www.atmos-chem-phys-discuss.net/acp-2019-678/acp-2019-678-AC1supplement.pdf

Interactive comment on Atmos. Chem. Phys. Discuss., https://doi.org/10.5194/acp-2019-678, 2019. 